\title{
Persistent elevation of urine aquaporin-2 during water loading in a child with nephrogenic syndrome of inappropriate antidiuresis (NSIAD) caused by a R137L mutation in the V2 vasopressin receptor
}

\author{
Clement C Cheung ${ }^{1 *}$, Melissa A Cadnapaphornchai ${ }^{2}$, Sayali A Ranadive ${ }^{3}$, Stephen E Gitelman ${ }^{1}$ and \\ Stephen M Rosenthal ${ }^{1 *}$
}

\begin{abstract}
Nephrogenic Syndrome of Inappropriate Antidiuresis (NSIAD) is a novel disease caused by a gain-of-function mutation in the V2 vasopressin receptor (V2R), which results in water overload and hyponatremia. We report the effect of water loading in a 3-year old boy with NSIAD, diagnosed in infancy, to assess urine aquaporin-2 (AQP2) excretion as a marker for V2R activation, and to evaluate the progression of the disease since diagnosis. The patient is one of the first known NSIAD patients and the only patient with a R137L mutation. Patient underwent a standard water loading test in which serum and urine sodium and osmolality, serum AVP, and urine AQP2 excretion were measured. The patient was also evaluated for ad lib fluid intake before and after the test. This patient demonstrated persistent inability to excrete free water. Only $39 \%$ of the water load $(20 \mathrm{ml} / \mathrm{kg})$ was excreted during a 4-hour period (normal $\geq 80-90 \%$ ). Concurrently, the patient developed hyponatremia and serum hypoosmolality. Serum AVP levels were detectable at baseline and decreased one hour after water loading; however, urine AQP2 levels were elevated and did not suppress normally during the water load. The patient remained eunatremic but relatively hypodipsic during ad lib intake. In conclusion, this is the first demonstration in a patient with NSIAD caused by a R137L mutation in the V2R that urine AQP2 excretion is inappropriately elevated and does not suppress normally with water loading. In addition, this is the first longitudinal report of a pediatric patient with NSIAD diagnosed in infancy who demonstrates the ability to maintain eunatremia during ad lib dietary intake.
\end{abstract}

Keywords: Aquaporin-2, NSIAD, V2R, Water Loading

\section{Introduction}

Normal fluid balance requires an intact thirst mechanism and normal free water excretion by the kidneys, mediated by arginine vasopressin (AVP), also known as antidiuretic hormone (ADH). AVP exerts its antidiuretic action via the $\mathrm{V} 2$ vasopressin receptor (V2R) in the basolateral membrane of renal collecting duct cells. Binding and activation of the V2R, a G-protein coupled

\footnotetext{
* Correspondence: clement.cheung@ucsf.edu; rosenthals@peds.ucsf.edu 'Department of Pediatrics, Division of Endocrinology, University of California, San Francisco, San Francisco, CA 94143

Full list of author information is available at the end of the article

receptor (GPCR), increases intracellular cAMP and mediates shuttling of the water channel aquaporin-2 (AQP2) from cytosolic storage vesicles to the apical membrane of collecting duct cells, resulting in increased water permeability and antidiuresis [1]. A fraction of this AQP2 is excreted in the urine and has been found to be a useful marker of V2R activity [2]. Water loading in a normal individual suppresses plasma AVP levels and attenuates antidiuresis as a result of decreased AQP2 shuttling to the apical membrane of collecting duct cells. Consequently, less AQP2 is shed into the urine $[3,4]$. 
We have previously described a novel syndrome of impaired water excretion mediated by gain-of-function mutations in the X-linked gene for V2R in two unrelated male infants who presented with irritability or seizures and hyponatremia [5]. Their clinical and laboratory findings were consistent with the syndrome of inappropriate secretion of antidiuretic hormone (SIADH) yet their AVP levels were undetectable. We have termed this condition "nephrogenic syndrome of inappropriate antidiuresis" (NSIAD). Each patient carries a missense mutation in codon 137 of $A V P R 2$, which results in a change from arginine to cysteine (R137C) in one patient and to leucine (R137L) in the other [5]. Codon 137 is part of a highly conserved DRY/H motif located at the junction of the third transmembrane domain and the second intracellular loop of class 1 GPCRs. This motif is critical for Gprotein coupling [6] and the two mutations each resulted in a constitutively active V2R [5].

Since our initial description of NSIAD, many reports from around the world, including individual and family studies, have characterized the clinical course of this syndrome [7-12]. All of these patients have the R137C V2R mutation. Here we report the clinical course of the only known patient with NSIAD caused by the more potent R137L V2R mutation [5]. This patient demonstrated the ability to maintain eunatremia during ad lib dietary intake. However, urine AQP2 levels were elevated and did not suppress normally during a standard water loading test, consistent with a gain-of-function mutation of V2R.

\section{Patient and methods Patient}

CS first presented at 2.5 months of age with seizures and hyponatremia (118-120 mmol/L). His laboratory studies suggested SIADH; however, he had undetectable AVP levels on repeated occasions. DNA sequencing revealed a missense mutation in his $A V P R 2$ gene, resulting in a R137L gain-of-function mutation of the V2R [5]. Fluid restriction and oral urea resulted in eunatremia and normal growth and development. The patient was lost to follow-up between age 20-32 months, during which time urea was given only intermittently and ultimately discontinued by the family at age 30 months. Despite inconsistent or complete lack of intake of urea, periodic measurements of serum sodium concentration by his pediatrician were always within the normal range. He was admitted to our institution at age 36 months to assess his water metabolism and to determine need for ongoing urea treatment.

\section{Water loading test}

A water loading test $[4,13,14]$ was performed in the Pediatric Clinical Research Center at our institution. A peripherally-inserted central catheter and a Foley catheter were placed 24 hours prior to the test. The patient was monitored without fluid restriction for $24 \mathrm{hr}$. Baseline urine and blood were collected at 60 and 30 minutes prior to administration of water $[20 \mathrm{~mL} / \mathrm{kg}(360 \mathrm{~mL})$ over 30 minutes via nasogastric tube]. Urine and blood samples were collected every 30 and 60 minutes, respectively, for 4 hours for measurement of sodium and osmolality. In addition, serum AVP (Quest diagnostics) [5] and urine AQP2, creatinine, and urine volume were measured. After the test, the patient was observed on ad libitum dietary intake. Intake and output were monitored for an additional 72 hours. Of note, the same reference laboratory for serum AVP measurement was used throughout this child's life.

\section{Preparation of urine samples for urinary AQP2 analysis}

Urine samples were centrifuged at 4,000 g for $5 \mathrm{~min}$ to remove any debris. The supernatant was diluted 1:1 with 2 $\times$ sodium dodecyl sulfate (SDS) sample buffer containing 2-mercaptoethanol. The samples were heated for $15 \mathrm{~min}$ at $65^{\circ} \mathrm{C}$ and stored at $-20^{\circ} \mathrm{C}$ until analyzed. Just before loading for electrophoresis, samples were warmed to $37^{\circ} \mathrm{C}$.

\section{Development of AQP2 antibody}

As described previously [15], a rabbit polyclonal antibody against AQP2 was prepared by Gene-med Biotechnologies Inc., (San Francisco, CA, USA) using a synthetic peptide (VELHSPQSLPRGSKA) from the $\mathrm{COOH}$ terminus of AQP2 [16]. The peptide was conjugated to keyhole limpit hemocyanin (KHL) by a cystein sulfhydryl linkage. Test bleedings were screened by ELISA. Final titers were reported to be $>100,000$. In western blot analysis, the AQP2 antibody showed no reactivity to BSA.

\section{Urine AQP2 western blot}

AQP2 peptide was conjugated to BSA using the Imject Immunogen EDC conjugation kit (Pierce, Rockford, IL, USA). The AQP2 peptide conjugated BSA (AQP2-BSA) at varying concentrations and $10 \mu \mathrm{l}$ of the patient's sample at each time point were resolved on a $12 \%$ SDS-polyacrylamide gel and transferred to a polyvinylidine difluoride membrane. The membrane was incubated with the rabbit anti-human AQP2 antibody at $4^{\circ} \mathrm{C}$ overnight, washed, and incubated with anti-rabbit IgG horseradish peroxidase antibody (Amersham, Piscataway, NJ, USA) [15]. Immunoreactive bands were visualized by enhanced chemiluminescence (NEN Life Science). The bands of the AQP2BSA standards and the nonglycosylated form of AQP2 on the film were scanned and analyzed using NIH image software.

\section{Calculation of urinary AQP2 excretion}

After densitometry measurements, a standard curve was constructed of known amounts of AQP2-BSA versus 
densitometry measurements, and the densitometry measurements of the urine samples were converted to a numerical value calculated from the curve (Prism, Graph Pad, San Diego, CA, USA). Numerical values were reported as $\mathrm{pmol} / \mathrm{mg}$ creatinine. In initial studies, concentrations of AQP2 peptide conjugated BSA included 10, 20, 30, and $50 \mathrm{ng}$ [15]. However, with these concentrations of AQP2-BSA, the patient's samples for urine AQP2 were too high to accurately measure. Repeat immunoblots were performed with AQP2-BSA at 50, 100, 150, and $200 \mathrm{ng}$ as described above.

\section{Results}

\section{Pre-water loading test}

As initially reported at the time of NSIAD diagnosis, serum AVP was undetectable with concurrent hyponatremia, serum hypoosmolality, and inappropriately concentrated urine (Table 1). Following initiation of water restriction and urea treatment [17], serum sodium and osmolality normalized, associated with measurable serum AVP of $5.5 \mathrm{pg} / \mathrm{mL}$ (Table 1). Despite ad libitum fluid intake and subsequent discontinuation of urea, these values remained normal (Table 1).

\section{Water loading test}

Prior to the water loading test, the patient's serum sodium concentration was $135 \mathrm{mmol} / \mathrm{L}$, and serum and urine osmolality were $283 \mathrm{mmol} / \mathrm{L}$ and $857 \mathrm{mmol} / \mathrm{kg}$, respectively. An hour after the $20 \mathrm{~mL} / \mathrm{kg}$ water load, serum sodium was $128 \mathrm{mmol} / \mathrm{L}$, and serum and urine osmolality were $272 \mathrm{mmol} / \mathrm{L}$ and $709 \mathrm{mmol} / \mathrm{kg}$, respectively (Table 2). Over the next three hours, his serum sodium concentration remained stable and was 127 $\mathrm{mmol} / \mathrm{L}$ at the conclusion of the test, at which time his serum osmolality had decreased to $267 \mathrm{mmol} / \mathrm{L}$. Urine osmolality was inappropriately increased to $884 \mathrm{mmol} /$ $\mathrm{kg}$, exceeding the baseline value. Of note, serum AVP was $2.6 \mathrm{pg} / \mathrm{mL}$ at baseline and decreased to $1.1 \mathrm{pg} / \mathrm{mL}$ by one hour after water loading. Urine output during the 4hour test was $140 \mathrm{~mL}$, which was only $39 \%$ of the water load (normal $\geq 80-90 \%$ of the water load).

Intake and output during ad lib fluid intake

During the subsequent 3 days following the water loading test, the patient had free access to liquid based on
Table 2 Serum sodium, serum osmolality, and urine osmolality during standard water loading test $(20 \mathrm{~mL} / \mathrm{kg})$ at 3 years of age

\begin{tabular}{cccc}
\hline \multicolumn{4}{l}{ Water Loading Test } \\
\hline $\begin{array}{c}\text { Time } \\
\text { (min) }\end{array}$ & $\begin{array}{c}\text { Serum Na } \\
(\mathbf{1 3 4 - 1 4 3 ~} \mathbf{~ m m o l} / \\
\text { L) }\end{array}$ & $\begin{array}{c}\text { Serum Osm } \\
(\mathbf{2 8 5 - 2 9 4} \mathbf{~ m O s m /} \\
\mathbf{k g})\end{array}$ & $\begin{array}{c}\text { Urine Osm } \\
(\mathbf{3 0 0 - 9 0 0 ~} \mathbf{~ m O s m / ~} \\
\mathbf{~ g g})\end{array}$ \\
\hline-60 & 135 & 283 & 857 \\
+60 & 128 & 272 & 709 \\
+120 & 128 & 266 & 753 \\
+180 & 128 & 268 & 842 \\
+240 & 127 & 267 & 884 \\
\hline
\end{tabular}

his thirst. His daily intake was between $50-55 \mathrm{~mL} / \mathrm{kg} / 24$ $\mathrm{h}$ (normal fluid intake for weight is $75-80 \mathrm{~mL} / \mathrm{kg} / 24 \mathrm{~h}$ ) [18] whereas his 24 hour urine output remained at 30$35 \mathrm{~mL} / \mathrm{kg} / 24 \mathrm{hr}$. His serum sodium concentration was maintained between 131 and $139 \mathrm{mmol} / \mathrm{L}$ during this time.

\section{Urine aquaporin 2}

Quantitative immunoblot assay for urine AQP2 showed an abnormally elevated baseline of $420 \mathrm{pmol} / \mathrm{mg} \mathrm{Cr}$, which did not suppress normally for at least $3 \mathrm{hr}$ after water loading (87-98\% of baseline, where normal is 5$17 \%$ of baseline) [15] (Figures 1, 2). The AQP2-BSA standard curve for densitometry measurement is shown in Figure 3 [5].

\section{Discussion}

This is the first demonstration in a patient with NSIAD caused by the R137L V2R mutation of urinary AQP2 excretion which was markedly elevated at baseline and which did not suppress normally in a standard water loading test. Our patient's baseline urine AQP2 excretion exceeded that seen in normal adults following 12 hours of water deprivation (7-24 $\mathrm{pmol} / \mathrm{mg}$ creatinine; personal communication, F. Umenishi), a condition known to increase urine AQP2 excretion [3]. These findings of increased urinary AQP2 in our patient are consistent with a gain of function mutation in V2R.

Persistent urinary excretion of AQP2 during water loading has been reported in one patient with NSIAD [12] caused by the less potent R137C mutation [5]. In

Table 1 Serum sodium (Na) concentration, serum osmolality (Osm), serum AVP, and urine osmolality from initial evaluation at 2.5 months to 3 years of age

\begin{tabular}{|c|c|c|c|c|c|}
\hline Age & Events & $\begin{array}{c}\text { Serum Na } \\
(134-143 \\
\mathrm{mmol} / \mathrm{L})\end{array}$ & $\begin{array}{c}\text { Serum Osm } \\
(285-293 \\
\mathrm{mOsm} / \mathrm{kg})\end{array}$ & $\begin{array}{c}\text { Serum AVP } \\
(1.0-13.3 \\
\mathrm{pg} / \mathrm{mL})\end{array}$ & $\begin{array}{c}\text { Urine Osm } \\
(300-900 \\
\text { mOsm/kg) }\end{array}$ \\
\hline $2.5 \mathrm{~m}$ & Initial presentation & 118 & 247 & $<1$ & 390 \\
\hline $5.5 \mathrm{~m}$ & After 1 month of water restriction and urea & 142 & 295 & 5.5 & $\mathrm{n} / \mathrm{a}^{*}$ \\
\hline $3 \mathrm{yr}$ & Off urea for $>6$ months; ad lib intake & 139 & 295 & 3.1 & 628 \\
\hline
\end{tabular}

${ }^{*} \mathrm{n} / \mathrm{a}=$ not available 


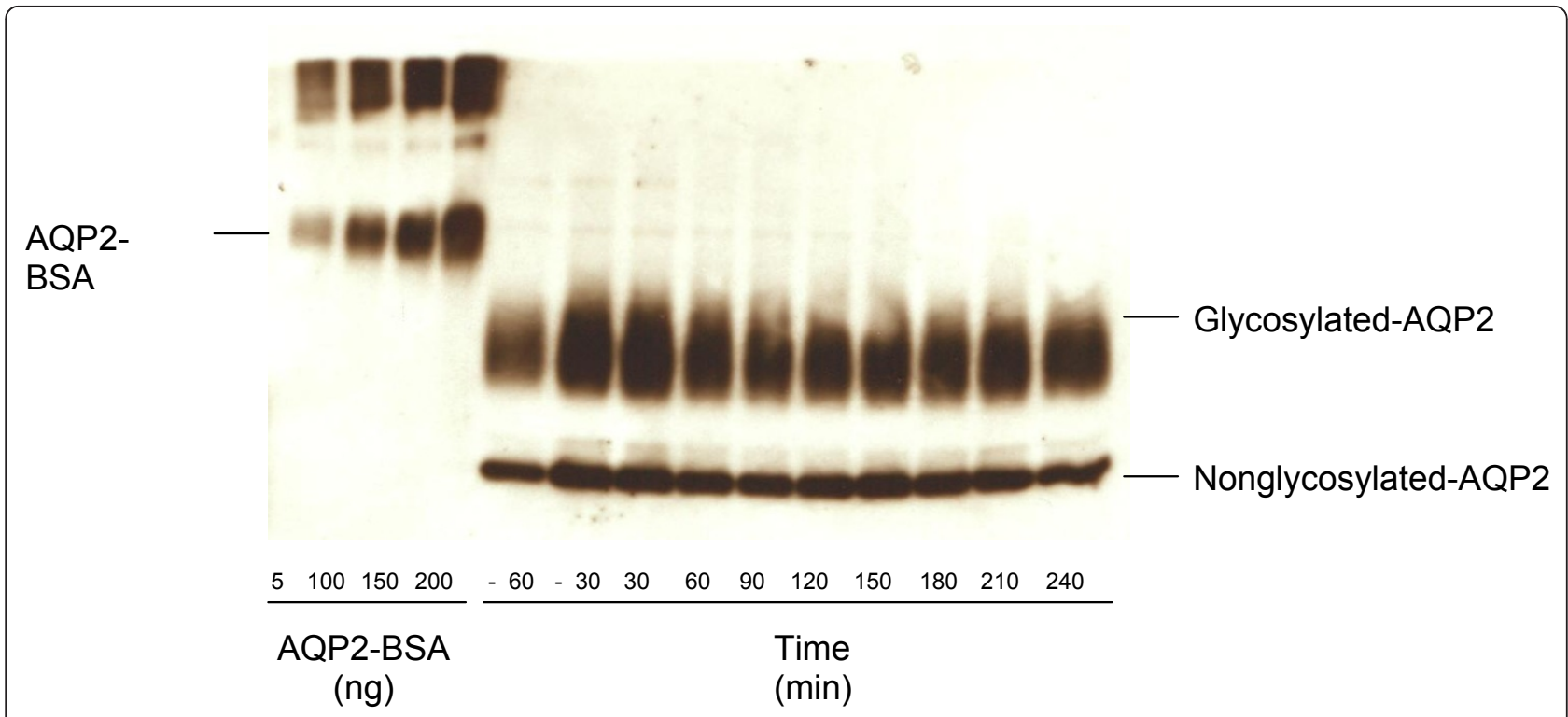

Figure 1 Western immunoblot showing urine AQP2 excretion from 60 minutes prior to 240 minutes following oral water load. AQP2BSA standards included 50, 100, 150, and $200 \mathrm{ng}$.

addition, altered urinary excretion of AQP2 has been described in several human diseases of pathological AVP secretion. A decrease or increase in urinary AQP2 levels was shown to correspond with diminished or exaggerated levels of AVP, as seen in central diabetes insipidus or SIADH, respectively $[3,4]$. In normal individuals, water loading reduces antidiuresis and, as expected, urine AQP2 levels $[3,15]$. In studies of water loading in normal adults, urine AQP2 excretion at 2 hours after an oral water load of $20 \mathrm{~mL} / \mathrm{kg}$ was reduced to $10 \%$ of baseline [15]. In the absence of appropriate diuresis during water loading, NSIAD patients would be predicted

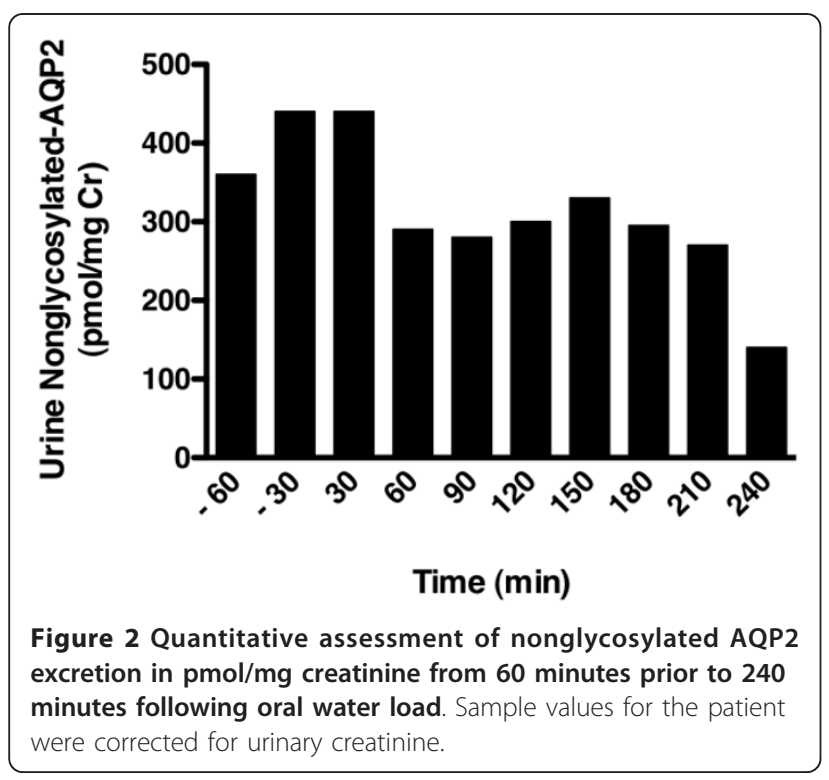

to have persistently elevated urine AQP2 levels. This is demonstrated in the R137C V2R mutation patient who received $50 \%$ of a standard water load [12] and confirmed by the results of our patient, who received the standard water load, in which urine AQP2 levels did not suppress normally, falling to only $87-98 \%$ of baseline for up to 3.5 hours after water loading.

The patient's serum AVP levels merit discussion. AVP levels were undetectable $(<1 \mathrm{pg} / \mathrm{ml})$ on initial presentation with hyponatremia during infancy, leading us to the identification of an activating V2R mutation [5]. Following normalization of the patient's hydration status with fluid restriction and oral urea supplementation, AVP levels were in the normal range $(5.5 \mathrm{pg} / \mathrm{ml})$. AVP levels were again in the normal range $(3.1 \mathrm{pg} / \mathrm{ml}) 6$ months following self-discontinuation of urea, associated with eunatremia and hypodipsia. Furthermore, during the water loading challenge, serum AVP levels decreased from a baseline of $2.6 \mathrm{pg} / \mathrm{mL}$ to $1.1 \mathrm{pg} / \mathrm{mL}$, the approximate assay limit of detectability, by one hour, when the patient had developed hyponatremia and serum hypoosmolality. Water loading in a patient with $\mathrm{R} 137 \mathrm{C}$ mutation also resulted in low but detectable serum AVP level [10]. Thus, despite the presence of a constitutively active V2R, these results indicate appropriate regulation of AVP secretion in NSAID. Possible explanations for the low but detectable AVP levels following water loading in NSIAD include contamination with platelet-bound AVP [19] and/or a slight vasovagal stimulus that may have exerted a non-osmotic effect that resulted in an incomplete suppression of AVP secretion.

It is noteworthy that this patient demonstrated an intact thirst mechanism and relative hypodipsia, 


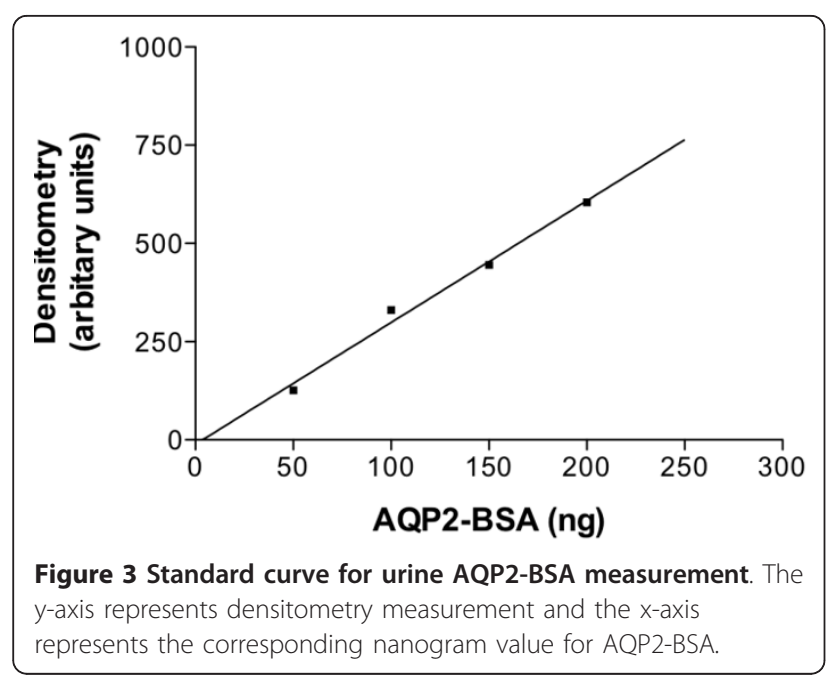

allowing him to maintain serum sodium in the 131-139 $\mathrm{mmol} / \mathrm{L}$ range under ad lib conditions. His relative basal eunatremia is likely a consequence of a diet that is no longer exclusively liquid and is in marked contrast to the severe hyponatremia observed at initial presentation, when the infant was exclusively formula-fed. From a dietary standpoint, our results concur with a previous report in which a child with NSIAD, diagnosed retrospectively, remained eunatremic after transition to solid food and discontinuation of sodium supplementation $[7,8,11]$.

An individual with NSIAD may escape detection during infancy if the activating V2R mutation is mild and/or if overhydration sufficient to induce hyponatremia does not occur. A report by Decaux et al. of a large pedigree of NSIAD patients caused by the R137C mutation in V2R highlights the marked variability in clinical presentation of this disorder [9]. One affected hemizygous male was apparently asymptomatic throughout life, and was discovered only after being administered a water loading test. Similarly, two other hemizygous adult males were discovered only when their 8 week old nephew was diagnosed with the disease and genetic testing was performed on the family [8]. One of the adult males was completely asymptomatic throughout his life and the other apparently has had generalized tonic-clonic seizures early in life of unknown etiology. In addition, several heterozygous females demonstrated inappropriate antidiuresis during water loading $[8,10,12]$. Thus, NSIAD may be more prevalent in the general population than would have otherwise been predicted based on the relatively small number of patients diagnosed in infancy.

In conclusion, this is the first report that urinary AQP2 levels in a patient with NSIAD caused by the R137L V2R mutation are elevated at baseline and do not suppress appropriately in response to water loading. This study demonstrates that urinary AQP2 can be a useful marker of V2R activity in NSIAD. Thus, increased urinary AQP2 excretion, in the setting of euvolemic hyponatremia and low or undetectable levels of serum AVP, suggests the possibility of NSIAD. This diagnosis should be confirmed by sequencing of $A V P R 2$.

\section{Consent}

Written informed consent was obtained from the patient for publication of this case report and any accompanying images. A copy of the written consent is available for review by the Editor-in-Chief of this journal.

\section{Acknowledgements}

This paper is supported by a grant (K08 DK076721-01) to Dr. Cheung, a training grant (T32-DK007161) to Dr. Ranadive, and a grant (RR024131-01) to the Pediatric Clinical Research Center.

\section{Author details}

'Department of Pediatrics, Division of Endocrinology, University of California, San Francisco, San Francisco, CA 94143. ${ }^{2}$ Department of Pediatrics, Division of Nephrology, University of Colorado Denver, Aurora, CO 80045. ${ }^{3}$ Pediatric Endocrinology, Palo Alto Medical Foundation, Fremont, CA 94538.

\section{Authors' contributions}

CCC and SMR designed the study, performed the analysis, and drafted the manuscript. MAC performed the western blot analysis. SAR and SEG participated in the design of the study. All authors read and approved the final manuscript.

\section{Competing interests}

The authors declare that they have no competing interests.

Received: 20 December 2011 Accepted: 10 February 2012

Published: 10 February 2012

\section{References}

1. Schrier RW, Cadnapaphornchai MA: Renal aquaporin water channels: from molecules to human disease. Prog Biophys Mol Biol 2003, 81:117-131.

2. Elliot $S$, Goldsmith P, Knepper M, Haughey M, Olson B: Urinary excretion of aquaporin-2 in humans: a potential marker of collecting duct responsiveness to vasopressin. J Am Soc Nephrol 1996, 7:403-409.

3. Kanno K, Sasaki S, Hirata Y, Ishikawa S, Fushimi K, et al: Urinary excretion of aquaporin-2 in patients with diabetes insipidus. N Engl J Med 1995, 332:1540-1545.

4. Saito T, Ishikawa SE, Ando F, Okada N, Nakamura T, et al: Exaggerated urinary excretion of aquaporin-2 in the pathological state of impaired water excretion dependent upon arginine vasopressin. J Clin Endocrinol Metab 1998, 83:4034-4040.

5. Feldman BJ, Rosenthal SM, Vargas GA, Fenwick RG, Huang EA, et al: Nephrogenic syndrome of inappropriate antidiuresis. N Engl J Med 2005, 352:1884-1890.

6. Gether U, Kobilka BK: G protein-coupled receptors. II. Mechanism of agonist activation. J Biol Chem 1998, 273:17979-17982.

7. Bes DF, Mendilaharzu H, Fenwick RG, Arrizurieta E: Hyponatremia resulting from arginine vasopressin receptor 2 gene mutation. Pediatr Nephrol 2007, 22:463-466.

8. Cho YH, Gitelman S, Rosenthal S, Ambler G: Long-term outcomes in a family with nephrogenic syndrome of inappropriate antidiuresis. Int $J$ Pediatr Endocrinol 2009, 2009:431527.

9. Decaux G, Vandergheynst F, Bouko Y, Parma J, Vassart G, et al: Nephrogenic syndrome of inappropriate antidiuresis in adults: high phenotypic variability in men and women from a large pedigree. J Am Soc Nephrol 2007, 18:606-612.

10. Gupta S, Cheetham TD, Lambert HJ, Roberts C, Bourn D, et al: Thirst perception and arginine vasopressin production in a kindred with an 
activating mutation of the type 2 vasopressin receptor: the pathophysiology of nephrogenic syndrome of inappropriate antidiuresis. Eur J Endocrinol 2009, 161:503-508.

11. Marcialis MA, Faa V, Fanos V, Puddu M, Pintus MC, et al: Neonatal onset of nephrogenic syndrome of inappropriate antidiuresis. Pediatr Nephrol 2008, 23:2267-2271.

12. Ranchin B, Boury-Jamot M, Blanchard G, Dubourg L, Hadj-Aissa A, et al: Familial nephrogenic syndrome of inappropriate antidiuresis: dissociation between aquaporin-2 and vasopressin excretion. J Clin Endocrinol Metab 2010, 95:E37-43.

13. Goldman MB, Luchins DJ, Robertson GL: Mechanisms of altered water metabolism in psychotic patients with polydipsia and hyponatremia. $N$ Engl J Med 1988, 318:397-403.

14. Pedersen RS, Bentzen H, Bech JN, Nyvad O, Pedersen EB: Urinary aquaporin- 2 in healthy humans and patients with liver cirrhosis and chronic heart failure during baseline conditions and after acute water load. Kidney Int 2003, 63:1417-1425.

15. Umenishi F, Summer SN, Cadnapaphornchai M, Schrier RW: Comparison of three methods to quantify urinary aquaporin-2 protein. Kidney Int 2002, 62:2288-2293

16. Nielsen S, DiGiovanni SR, Christensen El, Knepper MA, Harris HW: Cellular and subcellular immunolocalization of vasopressin-regulated water channel in rat kidney. Proc Natl Acad Sci USA 1993, 90:11663-11667.

17. Huang EA, Feldman BJ, Schwartz ID, Geller DH, Rosenthal SM, et al: Oral urea for the treatment of chronic syndrome of inappropriate antidiuresis in children. J Pediatr 2006, 148:128-131.

18. Holliday MA, Segar WE: The maintenance need for water in parenteral fluid therapy. Pediatrics 1957, 19:823-832.

19. Kluge M, Riedl S, Erhart-Hofmann B, Hartmann J, Waldhauser F: Improved extraction procedure and RIA for determination of arginine8-vasopressin in plasma: role of premeasurement sample treatment and reference values in children. Clin Chem 1999, 45:98-103.

doi:10.1186/1687-9856-2012-3

Cite this article as: Cheung et al:: Persistent elevation of urine aquaporin-2 during water loading in a child with nephrogenic syndrome of inappropriate antidiuresis (NSIAD) caused by a R137L mutation in the V2 vasopressin receptor. International Journal of Pediatric Endocrinology 2012 2012:3.

\section{Submit your next manuscript to BioMed Central and take full advantage of:}

- Convenient online submission

- Thorough peer review

- No space constraints or color figure charges

- Immediate publication on acceptance

- Inclusion in PubMed, CAS, Scopus and Google Scholar

- Research which is freely available for redistribution

Submit your manuscript at www.biomedcentral.com/submit 